\title{
The Place of Meat in Dietary Policy: An Exploration of the Animal/Plant Divide
}

\author{
Frédéric Leroy ${ }^{1 *}$ and Adele H. Hite ${ }^{2}$ \\ ${ }^{1}$ Research Group of Industrial Microbiology and Food Biotechnology (IMDO), Faculty of Sciences and \\ Bioengineering Sciences, Vrije Universiteit Brussel, Pleinlaan 2, B-1050 Brussels, Belgium \\ ${ }^{2}$ Research scholar, Ronin Institute for Independent Scholarship, Montclair, NJ, USA \\ *Corresponding author. Email: frederic.leroy@vub.be (Frédéric Leroy)
}

\begin{abstract}
The virtues of "plant-based" eating are commonly extolled in public and academic discourse, in particular in postindustrial countries and exceedingly so on a global level. Animal source foods, on the other hand, are regularly stigmatized for their alleged link with disease, environmental deterioration, and animal abuse. Although there is a reasonable case for the improvement of animal agriculture, this discourse leads to a binary and counterproductive view of food systems: plants are largely seen as beneficial and animal source foods as intrinsically harmful. We argue that this animal/plant binary and the promotion of civic responsibility to accept it as such are cultural constructs that emerged in the Anglosphere during the 19th century. The divide has been continuously evolving since and is currently deepening due to a global sense of urgency, underpinned by various societal anxieties and normative responses. A symptomatic example is provided by the recent call for a Planetary Health Diet and a Great Food Transformation by the EAT-Lancet Commission and its wider network.
\end{abstract}

Key words: meat, veganism, vegetarianism, health, sustainability, animal agriculture

Meat and Muscle Biology 4(2): 2, 1-11 (2020) doi:10.22175/mmb.9456

Submitted 17 December $2019 \quad$ Accepted 20 February 2020

This paper was accepted as a contribution to the 2020 International Congress of Meat Science and Technology and the AMSA Reciprocal Meat Conference.

\section{Introduction}

While meat has been cherished as valuable food by most humans during most of their history for its contributions to biosocial well-being and sustenance (Leroy and Praet, 2015; Leroy and De Smet, 2019), its appreciation has become more ambiguous over recent decades (Leroy, 2019). Analysis of mass media communication data on the relationship between meat and health has shown that about half of the news items that were published in the online version of The Daily Mail during the first 15 years of this century represented meat as unhealthy, often in a sensationalist manner (Leroy et al., 2018a). The remaining items were either ambivalent or positive. Since then, the antimeat narrative has only been intensifying. The Guardian, another leading British newspaper, received a $\$ 886,600$ grant from the Open
Philanthropy Project in 2017 to publish a series that paints contemporary animal agriculture as mostly inhumane and harmful to humans and the environment ("Animals farmed"; OPP, 2017). This hard stance is not restricted to mass media as it is also being amplified in scientific literature. Moving to "plant-based" eating is defended by certain academics because it allegedly contributes to public health (e.g., Wolk, 2017), increases food security (e.g., Cassidy et al., 2013), prevents environmental harm (e.g., Poore and Nemecek, 2018), and reduces animal suffering (e.g., Deckers, 2016). Public and academic antimeat narratives are substantially intertwined (Leroy et al., 2018a), which is also reflected in national and global food policies. Below, we will exemplify the current state of affairs with a much debated, ambitious, and influential policy proposal aimed at profound dietary reform: the Planetary Health Diet. 


\section{Toward a Great Food Transformation?}

In November 2018, a mediatized study argued for a severe meat tax to improve public health (Springmann et al., 2018). Its first author was a member of the EATLancet Commission, a coalition of the nonprofit EAT and the medical journal The Lancet. Later that month, an editorial in that same journal argued that a healthy amount of meat is "very little," supporting a plea for targeted taxation (Anonymous, 2018). Early 2019, the Commission announced its plan for a Great Food Transformation (Lucas and Horton, 2019). The proposed diet, promoted as the Planetary Health Diet, is nearly vegetarian and allows for a vegan option (Willett et al., 2019). It refers to red meat as "unhealthy," only allowing a small daily dose (0-14 g).

The Commission is aware that such profound systemic change will fail if left to "the whim of consumer choice" (Willett et al., 2019), making a case for active shaping of public opinion and hard policies. EAT has placed itself within a strategic network by forging an alliance with leading food multinationals. This alliance (Food Reform for Sustainability and Health; https:// eatforum.org/initiatives/fresh) comprises members of the World Business Council for Sustainable Development (WBCSD) who publicly endorse the prospect of a more "plant-based" market (e.g., Gretler, 2018; Wood, 2018). In addition to the WBCSD, EAT connects with various (Silicon Valley-backed) innovative food industries, such as Beyond Meat and Impossible Foods (cf., EAT, 2019). Such companies envisage the elimination of livestock in the next 2 decades (Levitt, 2017; Garcia, 2019). Furthermore, EAT's network includes global quasigovernmental entities that seem interested in ensuring that those markets are supported politically, including the World Economic Forum (WEF; e.g., Whiting, 2019) and the United Nations Environment Programme (UNEP). Generally supportive of the Planetary Health Diet (e.g., UNEP, 2019; UN News, 2019), UNEP has also awarded Beyond Meat and Impossible Foods "Champions of the Earth" status in 2018, representing the United Nations' "highest environmental honor" (UNEP, 2018).

Together with UNEP, the WEF, and the WBCSD, EAT is part of a Global Commons Alliance (http:// globalcommonsalliance.org), which also involves its cofounder, the Stockholm Resilience Centre, andamong others - the International Institute for Applied Systems Analysis (IIASA), the World Resources Institute (WRI), and various business-linked platforms (e.g., the Natural Capital Coalition, We Mean Business Coalition, BSR, and Ceres). Together, EAT, the WRI, the WBCSD, and the IIASA constitute the Food and Land Use Coalition, which has proposed a $91 \%$ decrease of red meat for Australians by 2050, based on the Planetary Health Diet (Navarro-Garcia et al., 2019). The C40 Cities initiative, another business platform in which EAT (funder) and the WRI (network partner) are operative, has included total dietary exclusion of meat and dairy as one of the "ambitious targets" of its headline report (C40 Cities, 2019a). In October 2019 , the mayors of 14 global cities belonging to this initiative (e.g., London, Tokyo, Stockholm, Toronto, and Los Angeles) committed to achieving the Planetary Health Diet for all citizens by 2030 by introducing policies and using their procurement powers (C40 Cities, 2019b).

To redirect consumer choice, the WRI has suggested a set of strategies with varying degrees of compulsion, including taxation, exertion of influence over nutritional labelling and dietary guidelines, stimulation of 30-d diet challenges, nudging and interference at retail level, and the banning of meat from menus (Ranganathan et al., 2016). Although the latter option may seem extreme, it has been advocated by Christina Figueres (quoted in Vella, 2018), who is a member of the WRI's Board of Directors (WRI, 2019) and the former executive secretary of the United Nations Framework Convention on Climate Change. A plea for a total legal ban on animal products can be found in an academic study financially supported by the Wellcome Trust (Deckers, 2016), one of EAT's main funders (https://eatforum.org/about/who-we-are).

The EAT forum has not been immune to criticism (Leroy and Cohen, 2019; Sustainable Food Trust, 2019). After being pressured on its environmental claims, its science director declared that "the meat consumption limits proposed by the Commission were not set due to environmental considerations but were solely in light of health recommendations" (quoted in Mitloehner, 2019). The health claims, in turn, were dismissed as "improbable" (Leroy and Cofnas, 2020), "unjustified" (Alan Matthews, Trinity College Dublin's emeritus professor of agricultural policy, quoted in O'Sullivan, 2019), "flawed" (Zagmutt et al., 2019; Zagmutt et al., 2020), or "science fiction" (John Ioannidis, Stanford University's professor of medicine, health research, and policy, quoted in Bloch, 2019). The diet was said to overlook local context, risking unintended environmental and health impacts (Tuomisto, 2019), a concern echoed by Ethiopia's Minister of Agriculture (Gebreyohannes, 2019). 


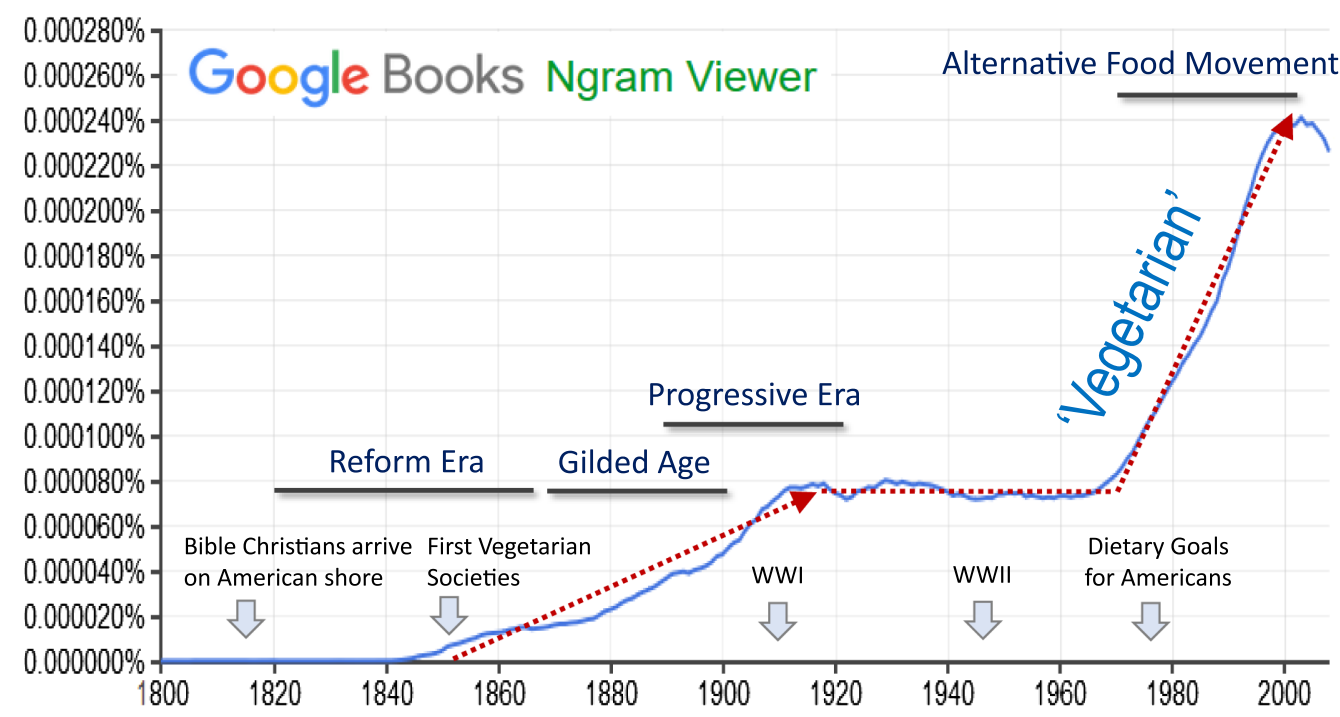

Figure 1. Use of the word "vegetarian" in books written in English for the period 1800-2008 according to Google Books Ngram Viewer, with the indication of relevant historical periods and events.

Italy's ambassador and permanent representative to the international organizations in Geneva warned about the impact of "centralized control of our dietary choices" on health, livelihoods, cultural heritage, and freedom of choice, questioning the diet's scientific basis (Torjesen, 2019), a critique reminiscent of Scrinis' (2008) concept of "nutritionism." A coalition of anthropologists made a similar charge, noting that EAT-Lancet's interventions are aimed at changing individual behavior in a way that ignores what may be truly at the root of endemic poor health: structural inequalities and histories of poverty and dispossession (Burnett et al., 2020).

To understand how the Global Food Transformation was able to acquire such a level of endorsement worldwide despite controversy, a historical perspective is needed to outline its "conditions of possibility". Such a perspective should help to clarify the deepening of the animal/plant divide, which is also likely to reflect the rise of vegetarianism (cf., Figure 1). We also refer to Hite (2019) for an in-depth exploration of the role of biopower, governmentality, and meta-genre in dietary policy making.

\section{Tracing the Origins of the Animal/Plant Divide}

\section{From religious self-restraint to the virtues of biological living}

Building on earlier minoritarian notions of asceticism and purity, a more pronounced moral distinction between animal and plant foods emerged in the Anglosphere during the early days of the Reform Movement, with the arrival of English Bible Christians on the American shore in 1817 (Shprintzen, 2013). As an affirmative act of temperance, reformists advocated a shift from rich food to bland alternatives (e.g., from meat with gravy to bran). Meat eating represented a departure from the natural Garden of Eden diet and was portrayed as sinful due to its overheating of body and mind, leading to the vices of carnal lust and masturbation. This view was further propagated in the 1830 s by Sylvester Graham and reinforced by the Seventh-day Adventist Church (Wilson, 2014).

Halfway through the century, Bible Christians founded vegetarian societies in England and the United States. This period is also characterized by infrastructural change of the food chain, leading to the industrialization of livestock (Ogle, 2013). Arguably, the disconnect from the process of slaughter may have added to the evolving attitudes toward animal killing and the creation of "postdomestic sensitivities" (Bulliet, 2005; Leroy and Praet, 2017; Buscemi, 2018). Dietary vegetarianism also reinforced protests against vivisection and was used as a catalyst for other progressive agendas, such as the emancipation of slaves, suffragism, and socialism, which peaked during the Progressive Era (1890s to1920s; Shprintzen, 2013). In addition, middle class anxieties due to widening income inequality pushed for more virtuous eating during the Gilded Age (1870s to 1900), symbolized by a diet based on whole grains rather than meat (Finn, 2017). Role models, such as bodybuilders and athletes, were used in popular media to link vegetarianism to 
muscularity, vitality, and success (Shprintzen, 2013), thereby attempting to invert the traditional symbolic value of meat (Leroy and Praet, 2015; Leroy, 2019). These themes continue to percolate through antimeat rhetoric today (e.g., the movie "The Game Changers").

Early on, reformists began to stress the beneficial effect of their diet on physiology, broadening its public appeal by introducing notions of medical expertise (Wilson, 2014). Like alcohol, meat was said to contain unnatural substances the digestion of which drained vital power and led to impure blood. Articles in the Graham Journal of Health and Longevity, Library of Health, and Water-Cure Journal referred to the virtues of plant diets and their effects on bodily functions, presenting numerous charts and figures. Blending theology and physiology, a diet based on vegetables and whole grains was said to clear the mind, improve digestion, eliminate kidney stones, keep circulation regular and cool, and lead to "a more perfect mode of being" (Shprintzen, 2013). In 1837, the American Physiological Society was founded in Boston and integrated Grahamite lifestyle into a physiological context of cleanliness, exercise, and sleep. One of its founders published a widely read plea for Grahamism in the Boston Medical and Surgical Journal (Alcott, 1836). Despite much controversy, this evolution placed dietary reform around avoiding meat within the realm of science.

During the Progressive Era, the reliance of vegetarianism on scientific models and expert authority to support a moral agenda became even more prominent (Ogle, 2013). Americans were urged to eat eggs, cheese, legumes, and nuts, while meat was no longer considered essential to a well-balanced diet (Shprintzen, 2013). Medical evangelism by the Seventh-day Adventist Church became particularly influential (Banta et al., 2018). One of its iconic members, John H. Kellogg, a medical doctor and superintendent of the Battle Creek Sanitarium, successfully promoted his theory of "biological living", combining Adventist beliefs with health reform and modernity. His invention of corn flakes, originally unsweetened, was primarily intended as bland, anaphrodisic food. Kellogg also commercialized Protose, Nuttose, and Granose as meat substitutes, promising a sensory experience close to meat eating and symbolizing competitive modern life (Shprintzen, 2013; Wilson, 2014).

During the first 2 decades of the 20th century, Americans were encouraged to not shun seemingly bizarre foods in the name of rational and moral eating, as science was applied to innovate agricultural production and food processing. By the end of World War I, the scientific language of getting adequately fueled by "protein," "carbohydrates," "calories," and "vitamins", rather than getting your meat and bread, became commonplace and infiltrated the curricula of public schools. As nutritionists were communicating that protein could be obtained from plants too, home economists and newspapers began praising protein-rich vegetarian dishes for their economic virtues. By deemphasizing tradition and reducing food to nutrients and calories, lentils with rice became interchangeable with steak. A cornucopia of novel foods was generated, including meat replacements (such as peanut butter) to the benefit of the agri-food industry (Veit, 2013). Industrially processed food became twice as valuable within the national economy than nonprocessed ones, obtaining a large part of their appeal from references to gourmet qualities and creativity. One of the main reasons for their success, of course, was the convenience that they offered (Ogle, 2013).

When the domestic science movement stepped in to teach people to "eat right" as a biological and social good, especially in the American Northeast, this dynamic was driven by the imposition of middle class values through seemingly neutral dietary advice (Biltekoff, 2013). As the Progressive Era established the idea that meat could be replaced based on nutritional norms (Buscemi, 2018), the halo of the moral superiority of plant foods remained.

\section{The path to social engineering: Creation of urgency and the appeal to civic duty}

In a next phase, mechanisms of urgency started to unfold within a tight normative framework. This was accompanied by democratic social engineering, acting as the dominant system of authority in the US throughout the 20th century, especially during wartime (Biltekoff, 2013). Around 1917, nutritional abundancy in the US was explicitly contrasted with starvation overseas in support of a planned food supply to European allies (Ogle, 2013; Veit, 2013). To generate feelings of American devotion to humanity, the case of "hungry Belgian children" was made (Veit, 2013). About $70 \%$ of the population were led into consuming less of daily staples such as beef, pork, white flour, butter, and sugar, for the simple reason that "concentrated foodstuffs" were easy to ship. Although the reason for this was purely practical, it also appealed to the prevailing reformist notions outlined earlier. Ascetic selfdiscipline was seen as a foundation for a productive and democratic society. In contrast, nonoptimal food choices-based on instinct, pleasure, and tradition 
rather than scientific design-were seen as making Americans less industrious. The organization of this reform policy by the Food Administration was supervised by Herbert Hoover, a Quaker and future US president. Its cultural authority was affirmed by referring to nutrition sciences, giving an aura of credibility to cheap sources of protein and calcium (e.g., peanut butter and cottage cheese) and foods that were previously seen as waste products. A comparison of high food prices with shortages abroad provided the mandate to rethink the entire dietary system, which changed the way society understood food and extended the state's reach into both public and private kitchens by making food choices a moral duty.

Despite broad support, urban unrest was seen with some people accusing the elites of "rolling themselves in all conceivable luxury" in response to the state's "Simple Life" message. Although a rationing system was within its power, the Food Administration preferred to rely on propaganda to generate voluntary compliance in the name of a greater good. "Meatless days" were introduced to develop esprit de corps by group abstinence, increasing social pressure. The entire campaign was rather effective: Americans ate less wheat, beef, pork, and sugar; some more corn, legumes, and potatoes; and a lot more rye, barley, buckwheat, margarine, nuts, and rice (Veit, 2013). Although Hoover was not in favor of whole grains, believing they caused dysentery, others such as the US Department of Agriculture's chief chemist Harvey Wiley strongly advocated their consumption. Whole grains presented an option to reduce food waste, as its refinement into white flour reduced the supply by one-third. As put by Veit (2013), this met "an emerging vision of American democracy whose participants did not need dictatorial control from the outside because they were already dictators of themselves."

A comparable situation existed during World War II, when "eating right" alleviated social anxiety at the home front, delineating ideals of good citizenship. With the knowledge of vitamins and essential nutrition, the eating of meat rather than abstention from it was depicted as a way to maintain the strength needed to guard the "home front" (Biltekoff, 2013). Ironically, sacred vegetarianism was meanwhile promoted in Nazi Germany for propagandistic reasons, to contrast purity of the race with impurity of "meat-devouring" (American) Jews (Buscemi, 2018).

The view of meat as a valuable foodstuff continued into the 1970s. When the first edition of the Dietary Goals for Americans married concerns about global hunger and ecology to a national nutrition policy to prevent chronic disease, some experts who opposed its antimeat sentiment argued that "Meat is a major contributor of vitamins, minerals, and protein in our diets [...] Like meat, milk and eggs are among our best foods [...] We need to consume more, not less" (Select Committee on Nutrition and Human Needs, 1977). Despite these protests, the Dietary Goals would reinforce, in the name of public health, anti-animal product discourse across the Anglosphere.

\section{The post-war dream of a Great Transition}

The groundwork for this ambitious public guidance toward a society free of chronic disease was laid in the decades succeeding World War II. Its language and practices constitute a discourse used to work toward social change, with repercussions for what it means to be a good citizen and how society should operate (Biltekoff, 2013). The scientific rationale for intervention is mostly tailored around arguments from nutritional epidemiology (Hite, 2019), referring, e.g., to the link between saturated fat and heart disease (e.g., Keys, 1968) or to studies of vegetarian groups, commonly found among Seventh-day Adventists (e.g., West and Hayes, 1968). The impact of Adventism on the received knowledge that vegetarian diets represent health can hardly be overstated, due to an ongoing stream of studies from its university in Loma Linda (e.g., Orlich et al., 2013) and its continuous involvement in the education of nutrition professionals (Banta, 2018). The American Dietetic Association (now Academy of Nutrition and Dietetics) was cofounded in 1917 by Lenna F. Cooper, a protégé of John H. Kellogg. Loma Linda University professors wrote the American Dietetic Association's first manual on vegetarian diets in 1973 and have continued to write and review position papers on vegetarianism for the dietetic profession since then (Shurtleff and Aoyagi, 2014). For a discussion on how and why the nutritional epidemiology of chronic disease shaped a new paradigm of "negative nutrition" that eventually ended up in the Dietary Goals, we refer to Hite (2019) and Biltekoff (2013).

In addition, views on meat were increasingly related to discourse from animal rights activism (Leroy and Praet, 2017), feminism (Adams, 1990), and ecology (Hite, 2019). With such influential books as Diet for a Small Planet (Lappé, 1971), the purpose of a "good" diet shifted to include both the nutritional and the environmental (Biltekoff, 2013). This gave rise to the "alternative food movement," celebrating eating as an ethical act and providing a new élan to 
vegetarianism (cf., Figure 1). Ecological virtue served as "the left's primary vehicle for outrage and hope" and reinforced a series of binary opposites in the countercuisine movement, such as plastic versus natural, white versus brown, and animal versus plant (Belasco, 1989). Besides being a tool for the fragmented, middle classes to affirm their status and a way to "reconnect to nature" in hectic urban settings, "eating right" shifted responsibility from the community level to the "environment", annihilating constraints of space (planet) and time (future), expanding the sphere of "eating right" to infinity (Biltekoff, 2013).

Added to the aforementioned, an ecologically framed business dynamic emerged after the 1972 Stockholm Conference and the later Rio Conference and Earth Charter movement of UNEP (Chatterjee and Finger, 1994). The latter were organized by Maurice Strong, UNEP's first executive director and a protagonist in the key organizations that now constitute the EAT-Lancet network, including the WRI, the IIASA, and the Stockholm Environment Institute and Beijer Institute of the Royal Swedish Academy of Sciences from which EAT's cofounder-Stockholm Resilience Centre-would arise. The WRI and the Stockholm Environment Institute are historical allies of the Tellus Institute and its Great Transition Initiative (https:// greattransition.org), a center for "futures studies" that does not shun New Age thinking (e.g., Rockefeller, 2015) and designs planetary transition scenarios (e.g., Raskin, 2002). The Great Food Transformation is firmly situated within that legacy while focusing on the dietary component. Through his role in the World Bank, the WEF, and the WBCSD, Maurice Strong has been an important catalyst for the public-private partnerships and development logic that were established in the 1970s to 1990s (Chatterjee and Finger, 1994) and are now a central tenet of the EAT approach.

\section{Dissolving the Binary}

We conclude that the provision of dietary advice to prevent chronic disease or to mitigate environmental concerns that is based purely on objective knowledge and rigorous science is improbable, given the context outlined earlier. In that sense, the Planetary Health Diet does not differ from earlier top-down models in that all of them should be considered as constructs shaped by politics and ideology rather than as empirical sets of rules (Scott, 1998). Regarding diet, they mostly offer a form of nutritionism (Scrinis, 2008) that focuses on the use of nutritional epidemiology to provide links between foods or food components and chronic diseases. The weaknesses and shortcoming of nutritional epidemiology of chronic disease precludes it as a means for establishing cause-effect relationships between foods and health outcomes (Hite, 2018). Regarding the environment, similar issues of weak methods applied to complex issues result in insufficient evidence to create guidance established on strong evidence (Friedberg, 2016). Together, however, these discourses provide measures for moral discourse and social comparison (Hite, 2019). With the rise of the alternative food movement, pleasurable eating became virtuous again but also reshaped the desires of the middle class around specialty products - often more expensive than animal-based foods - that would ostensibly have a lower environmental impact than meat, a trend that can be capitalized on by corporations (Biltekoff, 2013). This is exemplified by UNEP's praise of vegan burgers (UNEP, 2018), the WRI's nudging strategies (Bacon et al., 2019), and EAT's Planetary Health Shopping List (featuring items such as raw tahini, mango, fresh coriander, and nori; https://eatforum. org/learn-and-discover/weekly-shopping-list).

As far as the Planetary Health Diet is concerned, its "conditions of possibility" have only been met recently even though its blueprint goes back about 4 decades to the Dietary Goals and the Maurice Strong network. Increasing income inequality in the middle classes (Finn, 2017), highly mediatized food safety concerns (Leroy et al., 2018a), and alarms raised about climate change have only increased society's angst about what to eat (Biltekoff, 2013). Meat seems to take much of the blame in that process, acting as a convenient scapegoat (Leroy, 2019). The Great Food Transformation's insistence on the animal/plant binary should thus be seen primarily as a societal device rather than as the basis for robust nutrition or environmental policy. The evidence underlying its dietary health model is insufficient to warrant such an extreme view on dietary change (Zagmutt et al., 2020), most of it referring to overstated epidemiological studies that suffer from a healthy-user bias (Leroy and Cofnas, 2020), among other concerns (Trepanowski and Ioannidis, 2018). Nutritional epidemiological studies of chronic disease undertaken in the context of this historical discourse, which includes government policy that depicts whole grains as beneficial and red meat as harmful, reflect the eating habits of health-conscious, (upper) middle class professionals, who make up the bulk of the cohorts studied, rather than true diet-disease relationships; these studies were in turn legitimized by shifts in the framework of public health, which portrayed 
poor health as individual failure (Hite, 2018). As we have outlined, this discourse exceeds physiological grounds because it has been shaped by a range of factors, including ideology (e.g., that meat provokes lust while whole grains generate temperance) as well as pragmatism (e.g., meat was suitable for transport in World War I, while whole grains represented less waste than refined ones). As a result of culturally contingent healthy-user bias, the link between the eating of meat or animal fat and chronic disease observed in the US often tends to vanish when other geographical settings are surveyed (Dehghan et al., 2017; ACC, 2018), which is indicative of health beliefs rather than health effects (Leroy and Cofnas, 2020). As a recent set of papers indicates, both observational studies and clinical trials that attempt to link red meat to chronic disease provide only evidence of the lowest certainty (Vernooij et al., 2019; Zeraatkar et al., 2019). The researchers who performed those analyses assert that there is no way to determine, for any given individual, what the risks or benefits of eating meat might be (Johnston et al., 2019).

In fact, how the conclusions of these studies were received by other nutrition experts once more demonstrates the entanglement of science with other social, cultural, and economic factors. The studies used a rigorous systematic review methodology, known as Grading of Recommendations, Assessment, Development, and Evaluation (GRADE), to rate the certainty of evidence relating meat to cardiovascular, cancer, and mortality outcomes. The GRADE framework is a transparent and reproducible method for generating recommendations from available evidence, is considered an international standard, and is used by over 65 international organizations, including the World Health Organization (Mustafa et al., 2013). Yet when the aforementioned GRADE meat studies were published, Neal Barnard-president and founder of the Physicians Committee for Responsible Medicine, an advocacy group that promotes veganism-accused one of the researchers of undisclosed "conflicts of interest" (Dyer, 2020). The funding in question was not related to the studies at hand and was provided through an extension of Texas A\&M University that is a state agency affiliated with an academic institution and thus beyond minimum requirements for disclosure. Yet many interpreted these accusations as evidence of the animal product industry's efforts to "undercut the work of the medical community," as Barnard put it (Dyer, 2020). Yet Barnard's own ideological entanglements can also be used to argue that he was the one attempting to "undermine" the rigorous methods of the GRADE meat papers. If so, he was not alone.
Prominent Harvard researcher and first author of EAT-Lancet's dietary plan Walter Willett joined David Katz, founder and head of the True Health Initiative (THI), in campaigning to have the GRADE meat studies retracted prior to their publication, a very unusual move (Rubin, 2020). The campaign by the THI indicates that Katz broke embargo with the journal that published these studies (Annals of Internal Medicine) in order to generate interest in having the papers retracted. Even as the THI echoed and amplified the potential ties to the meat industry raised by Neal Barnard (who also signed the THI's request for retraction of the GRADE meat papers), the relationship of the THI to food corporations that make products supporting meat-free diets was seldom mentioned. Although the conclusions of the GRADE meat papers would seem to be as transparent and objective a review of the evidence as is possible, they were called into question by experts with their own economic and ideological interests because they did not align with the narrative produced by the animal/plant binary-that reducing meat consumption will preserve human and planetary health.

The animal/plant binary is thus problematic in many ways. It overstates the harm of animal source foods on both the nutritional and environmental front (White and Hall, 2017; Leroy et al., 2020). Animal agriculture will have to evolve, but it has the potential to meet and even serve the global sustainability agenda (FAO, 2018). Setting up a sustainable food chain without livestock agriculture, including ruminant production, is highly improbable. Moreover, the binary overlooks the vital benefits of animal source foods in the provision of adequate nutrition (Leroy et al., $2018 \mathrm{~b}$ ), from the intake of nutrients to their role in satiety and weight control (Wyness, 2016). The global nutritional challenges mostly relate to the provision of high-quality protein and a wide range of micronutrients (Nelson et al., 2018), in which animal foods play a key role (Leroy and Cofnas, 2020). Finally, the binary also risks giving the false impression that all is fine on the plant side of the division, which is far from being the case (Leroy et al., 2020). However, like the ties to industry maintained by the THI, these are seldom investigated or discussed.

\section{Conclusions}

The praxis of dietary reform during the last 200 years has resulted in the contemporary advice to eat less meat and more grains, vegetables, nuts, and fruit. 
It has contributed to the formation of an animal/plant divide, which amplifies its own message through the mechanism of healthy-user bias, affecting epidemiological literature through positive feedback. As an act that is both moral and scientific, "eating right" (e.g., less or no meat) has come to overrule tradition and preference, being at the same time consistent with the interests of the industrial order. Governmental intervention is welcomed by drawing support from the middle classes and activating social engineering. This evolution is problematic as food is no longer about culture, diversity, adequate nutrition, or even sustainability but is about how technocrats and their industrial allies measure and uniformize dietary needs within normative discourse, in view of societal management. The excessive focus on "plant-based" policies is not only counterproductive but also potentially harmful. It distracts from the actual planetary priorities that society should be dealing with, namely the root causes of climate change and inadequate nutrition because of nutrient-poor diets.

\section{Acknowledgments}

The authors acknowledge financial support of the Research Council of the Vrije Universiteit Brussel (in particular the IRP11 project "Tradition and naturalness of animal products within a societal context of change"). The authors wish to thank Belinda Fettke for the valuable suggestions.

\section{Literature Cited}

ACC. 2018. PURE: Healthy diet including dairy and meats may be good for hearts worldwide. American College of Cardiology, 28 August 2018. https://www.acc.org/latest-in-cardiology/articles/ 2018/08/22/14/15/tues-515am-pure-esc-2018. (Accessed 26 September 2019).

Adams, C. J. 1990. The sexual politics of meat: A feminist-vegetarian critical theory. Continuum Publishing Company, New York

Alcott, W. A. 1836. The Graham system. Boston Med. Surg. J. 14: 199-201. https://doi.org/10.1056/NEJM183605040141302.

Anonymous. 2018. We need to talk about meat. Lancet. 392:2237. https://doi.org/10.1016/S0140-6736(18)32971-4.

Bacon, L., J. Wise, S. Attwood, and D. Vennard. 2019. Language of sustainable diets: A field study exploring the impact of renaming vegetarian dishes on U.K. café menus. World Resources Institute. https://www.wri.org/publication/languagesustainable-diets. (Accessed 23 April 2020).

Banta, J. E., J. W. Lee, G. Hodgkin, Z. Yi, A. Fanica, and J. Sabate. 2018. The global influence of the Seventh-Day Adventist Church on diet. Religions. 9:251. https://doi.org/10.3390/ re19090251.
Belasco, W. 1989. Appetite for change: How the counterculture took on the food industry, 1966-1988. Cornell University Press, Ithaca, NY.

Biltekoff, C. 2013. Eating right in America: The cultural politics of food and health. Duke University Press, Durham, NC.

Bloch, S. 2019. World Health Organization drops its high-profile sponsorship of the EAT-Lancet diet. New Food Economy, 12 April 2019. https://newfoodeconomy.org/world-healthorganization-drops-its-high-profile-endorsement-of-the-eatlancet-diet. (Accessed 26 September 2019).

Bulliet, R. W. 2005. Hunters, herders and hamburgers: The past and future of human-animal relationships. Columbia University Press, New York/Chichester, West Sussex, UK.

Burnett, D., M. A. Carney, L. Carruth, S. Chard, M. Dickinson, A. Gálvez, et al. 2020. Anthropologists respond to the Lancet EAT Commission. Bionatura. 5:1023-1024. https://doi.org/ 10.21931/RB/2020.05.01.2.

Buscemi, F. 2018. From body fuel to universal poison: Cultural history of meat, 1900-the present. Springer, Cham, Switzerland.

Cassidy, E. S., P. C. West, J. S. Gerber, and J. A. Foley. 2013. Redefining agricultural yields: From tonnes to people nourished per hectare. Environ. Res. Lett. 8:034015. https://doi. org/10.1088/1748-9326/8/3/034015.

C40 Cities. 2019a. The future of human consumption in a $1.5^{\circ} \mathrm{C}$ world [C40 Cities headline report]. C40 Cities Climate Leadership Group, ARUP, and the University of Leeds. https://c40-production-images.s3.amazonaws.com/press_ releases/images/361_C40_CBE_MainReport_250719.original. pdf?1564075084. (Accessed 26 September 2019).

C40 Cities. 2019b. 14 cities commit to sustainable food policies that will address the global climate emergency. C40 Cities Climate Leadership Group. https://www.c40.org/press_releases/goodfood-cities. (Accessed 20 November 2019).

Chatterjee, P., and M. Finger. 1994. The earth brokers: Power, politics and world development. Taylor and Francis, New York, NY.

Deckers, J. 2016. Animal (de)liberation: Should the consumption of animal products be banned? Ubiquity Press, London.

Dehghan, M., A. Mente, X. Zhang, S. Swaminathan, W. Li, V. Mohan, R. Iqbal, R. Kumar, E. Wentzel-Viljjoen, A. Rosengren, L. I. Amma, A. Avezum, J. Chifamba, R. Diaz, R. Khatib, S. Lear, P. Lopez-Jaramillo, X. Liu, R. Gupta, N. Mohammadifard, N. Gao, A. Oguz, A. S. Ramli, P. Seron, Y. Sun, A. Szuba, L. Tsolekile, A. Wielgosz, R. Yusuf, A. H. Yusufali, K. K. Teo, S. Rangarajan, G. Dagenais, S. I. Bangdiwala, S. Islam, S. Anand, S. Yusuf, on behalf of the Prospective Urban Rural Epidemiology (PURE) study investigators. 2017. Associations of fats and carbohydrate intake with cardiovascular disease and mortality in 18 countries from five continents (PURE): A prospective cohort study. Lancet. 390:2050-2062. https://doi.org/10. 1016/S0140-6736(17)32252-3.

Dyer, O. 2020. Controversial red meat study adds correction over undisclosed industry funding. BMJ-Brit. Med. J. 368:m111. https://doi.org/10.1136/bmj.m111.

EAT. 2019. Dr. Patrick O. Brown, Founder \& CEO, Impossible Foods [About page]. EAT Forum. https://eatforum.org/ contributor/dr-patrick-o-brown. (Accessed 26 September 2019). 
FAO. 2018. World Livestock: Transforming the livestock sector through the Sustainable Development Goals. Food and Agriculture Organization of the United Nations, Rome. http://www.fao.org/3/CA1201EN/ca1201en.pdf. (Accessed 26 September 2019).

Finn, S. M. 2017. Discriminating taste: How class anxiety created the American food revolution. Rutgers University Press, New Brunswick, NJ.

Friedberg, S. 2016. Wicked nutrition: The controversial greening of official dietary guidance. Gastronomica. 16:69-80. https:// doi.org/10.1525/gfc.2016.16.2.69.

Garcia, T. 2019. Beyond Meat CEO wants to make traditional protein from animals 'obsolete.' MarketWatch, 6 May 2019. https://www.marketwatch.com/story/beyond-meat-wants-tomake-traditional-protein-from-animals-obsolete-2019-05-03. (Accessed 26 September 2019).

Gebreyohannes, G. 2019. Healthy sustainable diets for all: A view from Ethiopia. Thompson Reuters Foundation News, 7 February 2019. http://news.trust.org/item/20190207154412p07kz/. (Accessed 26 September 2019).

Gretler, C. 2018. Nestlé plans vegan push with no-meat burger, purple walnut milk. Bloomberg, 28 December 2018. https:// www.bloomberg.com/news/articles/2018-12-28/nestle-plansvegan-push-with-no-meat-burger-purple-walnut-milk. (Accessed 26 September 2019).

Hite, A. H. 2018. Nutritional epidemiology of chronic disease and defining "healthy diet". Global Food History. 4:207-225. https://doi.org/10.1080/20549547.2018.1498256.

Hite, A. H. 2019. A material-discursive exploration of "healthy food" and the Dietary Guidelines for Americans. Ph. D. dissertation, North Carolina State University, Raleigh, NC. (https://repository.lib.ncsu.edu/handle/1840.20/36530).

Johnston, B. C., D. Zeraatkar, M. A. Han, R. W. M. Vernooij, C. Valli, R. El Dib, C. Marshall, P J. Stover, S. Fairweather-Taitt, G. Wójcik, F. Bhatia, R. de Souza, C. Brotons, J. J. Meerpohl, C. J. Patel, B. Djulbegovic, P. Alonso-Coello, M. M. Bala, G. H. Guyatt. 2019. Unprocessed red meat and processed meat consumption: Dietary guideline recommendations from the Nutritional Recommendations (NutriRECS) consortium. Ann. Intern. Med. 171:756-764. https://doi.org/10.7326/ M19-1621.

Keys, A. 1968. Prevention of coronary heart disease. Official recommendations from Scandinavia. Circulation. 28:227-228. https://doi.org/10.1161/01.CIR.38.2.227.

Lappé, F. M. 1971. Diet for a small planet. Ballantine, New York.

Leroy, F. 2019. Meat as a pharmakon: An exploration of the biosocial complexities of meat consumption. Advances in Food and Nutrition Research. 87:409-446. https://doi.org/ 10.1016/bs.afnr.2018.07.002.

Leroy, F., and N. Cofnas. 2020. Should dietary guidelines recommend low red meat intake? [Published online 5 September 2019]. Crit. Rev. Food Sci. https://doi.org/10.1080/10408398.2019. 1657063.

Leroy, F., and M. Cohen. 2019. The EAT-Lancet Commission's controversial campaign. A global powerful action against meat? EFA News, 11 January 2019. https://www.efanews. eu/item/6053-the-eat-lancet-commission-s-controversialcampaign.html. (Accessed 26 September 2019).
Leroy, F., and S. De Smet. 2019. Meat in the human diet: A biosocial perspective. In: J. Lorenzo, P. Munekata, F. Barba, and F. Toldrá, editors, More than beef, pork and chickenThe production, processing, and quality traits of other sources of meat for human diet. Springer, Basel, Switzerland. p. 1-19.

Leroy, F., and I. Praet. 2015. Meat traditions: The co-evolution of humans and meat. Appetite. 90:200-211. https://doi.org/10. 1016/j.appet.2015.03.014.

Leroy, F., and I. Praet. 2017. Animal killing and postdomestic meat production. J. Agr. Environ. Ethic. 30:67-86. https://doi.org/ 10.1007/s10806-017-9654-y.

Leroy, F., M. Ben-Dor, and F. M. Mitloehner. 2020. Ethical defence of eating meat: The place of meat eating in ethical diets. In: T. Grandin, and M. Cockram, editors, The slaughter of farmed animals: Practical ways of enhancing animal welfare. CABI, Boston, MA. p. 301-308.

Leroy, F., M. Brengman, W. Ryckbosch, and P. Scholliers. 2018a. Meat in the post-truth era: Mass media discourses on health and disease in the attention economy. Appetite. 125:345355. https://doi.org/10.1016/j.appet.2018.02.028.

Leroy, F., T. Aymerich, M.-C. Champomier-Vergès, L. Cocolin, L. De Vuyst, M. Flores, F. Leroi, S. Leroy, R. Talon, R. F. Vogel, and M. Zagorec. 2018b. Fermented meats (and the symptomatic case of the Flemish food pyramid): Are we heading towards the vilification of a valuable food group? Int. J. Food Microbiol. 274:67-70. https://doi.org/10.1016/j. ijfoodmicro.2018.02.006.

Levitt, T. 2017. Impossible Foods CEO: We want to eliminate all meat from human diets. The Guardian, 8 July 2017. https:/ www.theguardian.com/sustainable-business/2017/jul/08/ impossible-foods-ceo-eliminate-meat-human-diets-veggieburger. (Accessed 26 September 2019).

Lucas, T., and R. Horton. 2019. The 21st-century great food transformation. Lancet, 393:386-387. https://doi.org/10.1016/ S0140-6736(18)33179-9.

Mitloehner, F. 2019. EAT-Lancet's environmental claims are an epic fail. And the Commission knows it (GHGGURU Blog). UC Davis, 19 February 2019. https://ghgguru.faculty. ucdavis.edu/2019/02/19/eat-lancet-report-is-an-epic-fail-andcommission-knows-it. (Accessed 26 September 2019).

Mustafa, R. A., N. Santesso, J. Brozek, E. A. Akl, S. D. Walter, G. Norman, M. Kulasegaram, R. Christensen, G. H. Guyatt, Y. Falck-Ytter, S. Chang, M. H. Murad, G. E. Vist, T. Lasserson, G. Gartlehner, V. Shukla, X. Sun, C. Whittington, P. N. Post, E. Lang, K. Thaler, I. Kunnamo, H. Alenius, J. J. Meerpohl, A. C. Alba, I. F. Nevis, S. Gentles, M. C. Ethier, A. Carrasco-Labra, R. Khatib, G. Nesrallah, J. Kroft, A. Selk, R. Brignardello-Petersen, H. J. Schünemann. 2013. The GRADE approach is reproducible in assessing the quality of evidence of quantitative evidence syntheses. J. Clin. Epidemiol. 66:736-742. https://doi.org/ 10.1016/j.jclinepi.2013.02.004.

Navarro-Garcia, J., R. Marcos-Martinez, D. Mason-D'Croz, M. Grundy, M. Hadjikakou, B. Bryan, and E. Court. 2019. Pathways to sustainable land-use and food systems in Australia by 2050. (2019 Report of the FABLE Consortium). International Institute for Applied Systems Analysis and the Sustainable Development Solutions Network. p. 88-107. https://www. foodandlandusecoalition.org/wp-content/uploads/2019/09/ 
Fableinterimreport_Australia_low.pdf. (Accessed 26 September 2019).

Nelson, G., J. Bogard, K. Lividini, J. Arsenault, M. Riley, T. B. Sulser, D. Mason-D’Croz, B. Power, D. Gustafson, M. Herrero, K. Wiebe, K. Cooper, R. Remans, and M. Rosegrant. 2018. Income growth and climate change effects on global nutrition security to mid-century. Nature Sustainability. 1:773-781. https://doi.org/10.1038/s41893018-0192-z.

Ogle, M. 2013. In meat we trust: An unexpected history of carnivore America. Houghton Mifflin Harcourt, New York.

OPP. 2017. Theguardian.org-Journalism on factory farming and farm animal cruelty. Open Philanthropy Project. https://www. openphilanthropy.org/focus/us-policy/farm-animal-welfare/ the-guardian-journalism-factory-farming. (Accessed 26 September 2019).

Orlich, M. J., P. N. Singh, J. Sabaté, K. Jaceldo-Siegl, J. Fan, S. Knutsen, W. L. Beeson, and G. E. Fraser. 2013. Vegetarian dietary patterns and mortality in Adventist Health Study 2. JAMA-Intern. Med. 17:1230-1238. https:// doi.org/10.1001/jamainternmed.2013.6473.

O'sullivan, K. 2019. No need for $90 \%$ drop in meat consumption, says Irish professor. The Irish Times, 19 January 1019. https:// www.irishtimes.com/news/health/no-need-for-90-drop-inmeat-consumption-says-irish-professor-1.3763038. (Accessed 26 September 2019).

Poore, J., and T. Nemecek. 2018. Reducing food's environmental impacts through producers and consumers. Science. 360:987992. https://doi.org/10.1126/science.aaq0216.

Ranganathan, J., D. Vennard, R. Waite, B. Lipinski, T. Searchinger, P. Dumas, et al. 2016. Shifting diets for a sustainable food future. World Resources Institute. https://wriorg.s3.amazonaws. com/s3fs-public/Shifting_Diets_for_a_Sustainable_Food_ Future_1.pdf?_ga=2.114696014.831878447.1548317259387216062.1543582872. (Accessed 26 September 2019).

Raskin, P. 2002. Great transition: The promise and lure of the times ahead. Stockholm Environment Institute, Boston, MA.

Rockefeller, S. 2015. The Earth Charter at 15: A spiritual lens on sustainability. Great Transition Initiative, https:// greattransition.org/publication/the-earth-charter-at-15. (Accessed 26 September 2019).

Rubin, R. 2020. Backlash over meat dietary recommendations raises questions about corporate ties to nutrition scientists. JAMA-J. Am. Med. Assoc. 323:401-404. https://doi.org/ 10.1001/jama.2019.21441.

Scott, J. C. 1998. Seeing like a state: How certain schemes to improve the human condition have failed. Yale University Press, New Haven, CT.

Scrinis, G. 2008. On the ideology of nutritionism. Gastronomica. 8:29-48. https://www.jstor.org/stable/10.1525/gfc.2008.8.1.39.

Select Committee on Nutrition and Human Needs. 1977. Dietary goals for the United States: Supplemental views. United States Senate.US Government Printing Office, Washington, D.C.

Shprintzen, A. D. 2013. The vegetarian crusade: The rise of an American reform movement, 1817-1921. University of North Carolina Press, Chapel Hill, NC.

Shurtleff, W., and A. Aoyagi. 2014. History of Seventh-Day Adventist work with soyfoods, vegetarianism, meat alternatives, wheat gluten, dietary fiber and peanut butter (1863-2013): Extensively annotated bibliography and sourcebook. Soyinfo Center, Lafayette, CA.

Springmann, M., D. Mason-D’Croz, S. Robinson, K. Wiebe, H. C. J. Godfray, M. Rayner, P. Scarborough. 2018. Health-motivated taxes on red and processed meat: a modelling study on optimal tax levels and associated health impacts. PLOS ONE. 13:e0204139. https://doi.org/10.1371/journal.pone. 0204139 .

Sustainable Food Trust. 2019. EAT-Lancet report's recommendations are at odds with sustainable food production. 17 January 2019. https://sustainablefoodtrust.org/articles/eat-lancetreports-recommendations-are-at-odds-with-sustainable-foodproduction/. (Accessed 26 September 2019).

Torjesen, I. 2019. WHO pulls support from initiative promoting global move to plant based foods. BMJ-Brit. Med. J. 365:11700. https://doi.org/10.1136/bmj.11700.

Trepanowski, J., and J. Ioannidis. 2018. Perspective: limiting dependence on nonrandomized studies and improving randomized trials in human nutrition research: Why and how. Advancd Nutrition. 9:367-377. https://doi.org/10.1093/ advances/nmy014.

Tuomisto, H. L. 2019. The complexity of sustainable diets. Natural Ecology \& Evolution. 3:720-721. https://doi.org/10.1038/ s41559-019-0875-5.

UN News. 2019. Food choices today, impact health of both 'people and planet' tomorrow. United Nations, 6 February 2019. https://news.un.org/en/story/2019/02/1032111. (Accessed 26 September 2019).

UNEP. 2018. Plant-based meat revolutionaries win UN's highest environmental honor. United Nations Environment Programme, 28 September 2018 [press release]. https://www. unenvironment.org/news-and-stories/press-release/plant-basedmeat-revolutionaries-win-uns-highest-environmental-honor. (Accessed 26 September 2019).

UNEP. 2019. Towards a "Great Food Transformation." United Nations Environment Programme, 19 February 2019. https:// www.unenvironment.org/news-and-stories/story/towards-greatfood-transformation. (Accessed 26 September 2019).

Veit, H. Z. 2013. Modern food, moral food: Self-control, science, and the rise of modern American eating in the early twentieth century. University of North Carolina Press, Chapel Hill, NC.

Vella, H. 2018. Christiana Figueres' radical ideas for feeding the many. Raconteur, 12 December 2018. https://www. raconteur.net/sustainability/christiana-figueres-food-production. (Accessed 26 September 2019).

Vernooij, R. W. M., D. Zeraatkar, M. A. Han, R. El Dib, M. Zworth, K. Milio, D. Sit, Y. Lee, H. Gomaa, C. Valli, M. J. Siwerz, Y. Chang, S. E. Hanna, P. M. Brauer, J. Sievenpiper, R. de Souza, P. Alonso-Coello, M. M. Bala, G. H. Guyatt, B. C. Johnston. 2019. Patterns of red and processed meat consumption and risk for cardiometabolic and cancer outcomes: A systematic review and meta-analysis of cohort studies. Ann. Intern. Med. 171:732-741. https://doi.org/10.7326/M19-1583.

West, E. O., and O. B. Hayes. 1968. Diet and serum cholesterol levels: a comparison between vegetarians and nonvegetarians in a Seventh-day Adventist group? Am. J. Clin. Nutr. 21:853-862. https://doi.org/10.1093/ajen/21.8.853. 
White, R. R., and M. B. Hall. 2017. Nutritional and greenhouse gas impacts of removing animals from US agriculture. P. Natl. Acad. Sci. USA. 114:E10301-E10308. https://doi.org/10. 1073/pnas. 1707322114 .

Whiting, K. 2019. Why we all need to go on the 'planetary health diet' to save the world. World Economic Forum, 17 January 2019. https://www.weforum.org/agenda/2019/01/why-we-allneed-to-go-on-the-planetary-health-diet-to-save-the-world. (Accessed 26 September 2019).

Willett, W., J. Rockström, B. Loken, M. Springmann, T. Lang, S. Vermeulen, T. Garnett, D. Tilman, F. DeClerck, A. Wood, M. Jonell, M. Clark, L. J. Gordon, J. Fanzo, C. Hawkes, R. Zurayk, J. A. Rivera, W. De Vries, L. M. Sibanda, A. Afshin, A. Chaudhary, M. Herrero, R. Agustina, F. Branca, A. Lartey, S. Fan, B. Crona, E. Fox, V. Bignet, T. Troell, T. Lindahl, S. Singh, S. E. Cornell, K. S. Reddy, S. Narain, S. Nishtar, C. J. L. Murray. 2019. Food in the Anthropocene: The EAT-Lancet Commission on healthy diets from sustainable food systems. Lancet. 393:447-492. https:// doi.org/10.1016/S0140-6736(18)31788-4.

Wilson, B. C. 2014. Dr. John Harvey Kellogg and the religion of biologic living. Indiana University Press, Bloomington, IN.

Wolk, A. 2017. Potential health hazards of eating red meat. J. Intern. Med. 281:106-122. https://doi.org/10.1111/joim. 12543.

Wood, Z. 2018. Unilever buys meat-free food company The Vegetarian Butcher. The Guardian, 19 December 2018. https://www.theguardian.com/business/2018/dec/19/unileverjoins-meat-free-revolution-after-buying-the-vegetarian-butcher. (Accessed 26 September 2019).

WRI. 2019. Board of Directors. World Resources Institute. https://www.wri.org/about/board. (Accessed 26 September 2019).

Wyness, L. 2016. The role of red meat in the diet: Nutrition and health benefits. P. Nutr. Soc. 75:227-232. https://doi.org/ $10.1017 /$ S0029665115004267.

Zagmutt, F. J., J. G. Pouzou, and S. Costard. 2019. The EAT-Lancet Commission: A flawed approach? Lancet. 394:1140-1141. https://doi.org/10.1016/S0140-6736(19)31903-8.

Zagmutt, F. J., J. G. Pouzou, and S. Costard. 2020. The EAT-Lancet Commission's dietary composition may not prevent noncommunicable disease mortality. J. Nutr. nxaa020. https://doi.org/ 10.1093/jn/nxaa020.

Zeraatkar, D., B. C. Johnston, J. Bartoszko, K. Cheung, M. M. Bala, C. Valli, M. Rabassa, D. Sit, K. Milio, B. Sadeghirad, A. Agarwal, A. M. Zea, Y. Lee, M. A. Han, R. W. M. Vernooij, P. A.-C., G. H. Guyatt, R. El Dib. 2019. Effect of lower versus higher red meat intake on cardiometabolic and cancer outcomes: A systematic review of randomized trials. Ann. Intern. Med. 171:721-731. https://doi.org/10.7326/ M19-0622. 